\title{
Introducing Artistic Research to Georgia
}

\author{
Nino Jvania* and Tamar Zhvania \\ Vano Sarajishvili Tbilisi State Conservatoire, Tbilisi, Georgia
}

\section{ARTICLE INFO}

\section{Keywords:}

Artistic Research

Music Education

Piano

Piano Music

Research

\begin{abstract}
Artistic research researches the creative process resulting into an art work. It shares the aim of any scientific research, contributing to accumulation of knowledge in a given field, though it frees a researcher from excessive formalities (such as obligatory research outcomes stated in a written form this function could be taken over by a piece of art), building the knowledge upon the practice. The notion of artistic research is a relatively new one. However, it has already been implemented at the academic level in several countries. Artistic research has never been conducted in the Republic of Georgia. Though, Tbilisi State Conservatoire offers to performers and composers' special doctoral programs that give doctoral students opportunities to examine issues related to performance and composition practice, based on theoretical and practical knowledge. The dissertations written in the framework of the programs to some extent relate to artistic research, though, they differ from artistic research in various aspects. The paper aims to reveal similarities and differences between those research forms and to present a research project Development of Artistic Research Methodology on the Example of Exploration of the Piano of the $21^{\text {st }}$ Century and its Future Perspectives. The project aims to enrich the given doctoral programs with elements of artistic research and later to contribute to implementation of artistic research on the academic level in Georgia. This experience could be taken into consideration by other countries that are on the way of implementing artistic research in their educational systems.
\end{abstract}

\section{Introduction}

The notion of artistic research is relatively new one. Not only its forms and principles, but even the definition is a subject of ongoing discussions ${ }^{1}$. According to one of the worldwide accepted (but not yet firmly established) definition, artistic research is concentrated on the creative process resulting into an art work. It studies the ideas inspiring artists to create a piece of art. Artistic research shares the aim of any scientific research, contributing to accumulation of knowledge in a given field, though, it frees a researcher from excessive formalities such as obligatory research outcomes stated in a written form - this function could be taken over by a piece of art through which the knowledge is built upon the practice.

Despite its young age, the artistic research has already been implemented at the academic level in several countries and it became equal of the scientific one. Republic of Georgia is not in the list of those countries. Though, it's worth mentioning that since 2011, Vano Sarajishvili Tbilisi State Conservatoire - the main institution of higher education in music in Georgia - offers to performers and composers special doctoral programs Performing Arts and Composition that give doctoral students the opportunity to examine issues related to performance and composition

\footnotetext{
${ }^{1}$ Nino Jvania herself participated in one of those discussions regarding the definition of artistic research, held in the framework of the AEC European Platform for Artistic Research in Music (EPARM) in 2015 in Graz, Austria.
}

*Corresponding author E-mail address: nino.jvania@tsc.edu.ge 
practice, based on theoretical and practical knowledge. The dissertations written in the framework of these programs to some extent relate to artistic research, though, they are conducted under different conditions. What are the similarities and differences between those research forms? Could the elements of artistic research be used to enrich the doctoral programs mentioned above?

\subsection{About Artistic Research}

Despite the fact that artistic research is a recent phenomenon, it is rooted in the history of artistic practice. Any piece of art could be considered as a result of a research conducted by an artist. Though, artistic research has developed into separate research form with its specific features determining its essence and one has to acknowledge that. It is conducted by artist-researchers who are willing to make statements about the process of creating art, about thoughts, concepts, ideas that their art is based upon.

Here, the researcher works as an insider, as a participant in the practice, as one of its embodiments, so to speak. But that is not all. In the practice itself, one also takes a step of minimal distance toward the practice, reflecting on it and on one's acts (Hannula et al., 2014, p. 16).

Artistic research methodology is in the process of development. For example, it is still questionable whether it should be bound to a word - to a written work. Though, it is a fact that the alternative to the scientific research, it contributes to development of the field. Johan Verbeke (2013) states that

"The arts, design and architecture are not involved in an exact logical understanding of our world (as are the exact sciences), but they complement this with a knowledge field which builds on human experience and behaviour and is interwoven with cultural and societal development. As with any other discipline, the arts, design and architecture build on their own specific positions in relation to reality. Additionally, they contribute to projecting into the future and are an important part of culture (p. 123)."

It is because of this special importance and role that artistic research has already been implemented at the academic level in several countries.

\subsubsection{Artistic Research in Music and Georgia}

There has been no precedent for conducting artistic research in the field of music in Republic of Georgia. The authors of the present paper, pianists Nino Jvania and Tamar Zhvania together with a composer Eka Chabashvili conduct the very first artistic research in Georgia - The Piano of the $21^{\text {st }}$ Century and its Future Perspectives. It comprises the analysis of development of the instrument in the $20^{\text {th }}$ and $21^{\text {st }}$ centuries in the context of historical development of academic music of the same period, as well as experiments with piano, aiming at finding new methods of sound-production and some ways of modification/transformation of piano. However, artistic research is not officially recognized research form by the state and the aim of the given project is to contribute to popularization of artistic research in Georgia, preparing future successful implementation of artistic research in the county. The research will serve as a Case Study which will support this process.

Though, as we already mentioned, Tbilisi State Conservatoire offers to performers and composers special doctoral programs Performing Arts and Composition that give doctoral students the opportunity to examine issues related to performance and composition practice ${ }^{2}$.

\footnotetext{
2 The doctoral programs Performing Arts and Composition grant the academic degree of Doctor of Musical Arts, while the doctoral program Musicological Researches grants the academic degree of Doctor of Art Criticism that is equivalent of PhD. (V. Sarajishvili Tbilisi State Conservatoire, n.d.). The same degrees are granted by similar doctoral programs at several other universities in Georgia.
} 
The doctoral dissertations defended in the framework of those programs are to some extant related to artistic research, though they don't represent this particular research form.

Table 1.

List of dissertations defended in 2011-2019 at Vano Sarajishvili Tbilisi State Conservatoire

\begin{tabular}{|c|c|c|c|}
\hline Name, Surname & $\begin{array}{l}\text { Doctoral program and } \\
\text { Specialty }\end{array}$ & Thesis Title & Year \\
\hline Ana Mamisashvili & $\begin{array}{l}\text { Performing Arts } \\
\text { Orchestral Instruments }\end{array}$ & $\begin{array}{l}\text { The 20th-century solo violin sonata } \\
\text { (Aspects of theory and performance) }\end{array}$ & 2019 \\
\hline $\begin{array}{l}\text { Medea } \\
\text { Kavtaradze }\end{array}$ & $\begin{array}{l}\text { Performing Arts } \\
\text { Academic Choir } \\
\text { Conducting }\end{array}$ & $\begin{array}{l}\text { Performing difficulties of the a cappella choral cycles by } \\
\text { Sulkhan Nasidze (on the examples of "PLEA" and "FROM } \\
\text { THE PERSIAN POETRY") }\end{array}$ & 2018 \\
\hline Levan Gomelauri & Composition & $\begin{array}{l}\text { The application methods of the verbal text as a part of the } \\
\text { composition techniques in the works of contemporary } \\
\text { Georgian composers (R. Kiknadze, L. Gomelauri, M. } \\
\text { Virsaladze, E. Chabashvili) }\end{array}$ & 2016 \\
\hline Mariana Asrieva & $\begin{array}{l}\text { Performing Arts } \\
\text { Orchestral Instruments }\end{array}$ & Some aspects of the baroque violin performance technique & 2014 \\
\hline $\begin{array}{l}\text { Levan Bagration- } \\
\text { Davitashvili }\end{array}$ & Composition & $\begin{array}{l}\text { The functions and methods of usage of percussive } \\
\text { instruments in works by Georgian composers }(1960 \text { - till } \\
\text { present) }\end{array}$ & 2014 \\
\hline $\begin{array}{l}\text { Zaira } \\
\text { Vadachkoria }\end{array}$ & $\begin{array}{l}\text { Performing Arts } \\
\text { Academic Choir } \\
\text { Conducting }\end{array}$ & $\begin{array}{l}\text { Issues of Interpretation of choral works by Joseph } \\
\text { Kechakmadze }\end{array}$ & 2012 \\
\hline Tamar Zhvania & $\begin{array}{l}\text { Performing Arts } \\
\text { Special Piano }\end{array}$ & Three-part inventions by J.S. Bach: issues of interpretation & 2012 \\
\hline $\begin{array}{l}\text { Natalia } \\
\text { Volchenko }\end{array}$ & $\begin{array}{l}\text { Performing Arts } \\
\text { Academic Singing }\end{array}$ & $\begin{array}{l}\text { Vocal methods by David Andghuladze: a defense } \\
\text { mechanism of phonetic apparatus }\end{array}$ & 2012 \\
\hline $\begin{array}{l}\text { Mamuka } \\
\text { Sikharulidze }\end{array}$ & $\begin{array}{l}\text { Performing Arts } \\
\text { Special Piano }\end{array}$ & Piano etudes by F. Chopin: issues of interpretation & 2012 \\
\hline Irina Aivazova & $\begin{array}{l}\text { Performing Arts } \\
\text { Collaborative Piano }\end{array}$ & $\begin{array}{l}\text { The vocal cycle by Mussorgsky "Songs and Dances of } \\
\text { Death" (some aspects of theory and performance practice) }\end{array}$ & 2012 \\
\hline Natia Azarashvili & $\begin{array}{l}\text { Performing Arts } \\
\text { Collaborative Piano }\end{array}$ & $\begin{array}{l}\text { Place and role of "Kindertotenlieder" in Mahler's work in } \\
\text { relation to performative tasks of an accompanist. }\end{array}$ & 2012 \\
\hline Ketevan Eliava & $\begin{array}{l}\text { Performing Arts } \\
\text { Academic Singing }\end{array}$ & $\begin{array}{l}\text { Problems of chamber vocal performance and vocal works } \\
\text { by Hugo Wolf }\end{array}$ & 2012 \\
\hline Nino Kasradze & $\begin{array}{l}\text { Performing Arts } \\
\text { Special Piano }\end{array}$ & $\begin{array}{l}\text { Problems of sound-production in piano music of the 20th } \\
\text { century on the example of work by O. Messiaen, }\end{array}$ & 2012 \\
\hline $\begin{array}{l}\text { Maya (Maka) } \\
\text { Virsaladze }\end{array}$ & Composition & $\begin{array}{l}\text { Aleatoric techniques in contemporary Georgian professional } \\
\text { music (on the example of works by N. Mamisashvili, R. } \\
\text { Kiknadze and E. Chabashvili) }\end{array}$ & 2011 \\
\hline Eka Chabashvili & Composition & On the concept of multi-topophonic composition technique & 2011 \\
\hline
\end{tabular}

Source: http://www.tsc.edu.ge/index.php?m=535\&lng=geo

Even the titles imply that the majority of dissertations relate to a certain extent to artistic research, representing mostly results of the research of the artistic practices. Despite the fact that they imitate musicological researches, copying particular academic stereotypes, the topics of dissertations imply participation of the researchers in the practice as an insider. Paraphrasing Jonathan Impett (2017), within doctoral programs mentioned above, performers and composers mostly conduct research through making music and not about making music (p. 11). 
Participation in practice is represented also by another obligatory part of the doctoral programs: performers have to perform certain works at concerts, composers - to compose works of certain genres. However, neither concerts nor works have to be related to dissertations. ${ }^{3}$ The so called "artistic" parts of doctoral programs just continue corresponding master's programs, only complicating requirements. Doctoral students specializing in solo piano, for instance, have to study a particular piano repertoire and to present it at concerts; and this repertoire does not have to be related (and mostly is unrelated) to the topic of the dissertation. Though, the works analyzed in their dissertations for the most part are represented in their repertoire. The same could be said about other specialties.

In contrast, the artistic research programs at many European universities, first and foremost, encourage artists to analyze the artistic practice of their own, and present conclusions in form of art. Consequently, there are researches in the field of music that result in compositions, audio and video recordings, concert series, lecture courses, with different types of a written report being only a part of research results. This research form seems to be much more useful for the majority of practicing musicians.

That is why, Nino Jvania, Eka Chabashvili and Tamar Zhvania conduct a project Development of Artistic Research Methodology on the Example of Exploration of the Piano of the $21^{\text {st }}$ Century and its Future Perspectives that aims to enrich the doctoral programs mentioned above with elements of artistic research.

The project comprises two related parts:

1. The study of artistic research methodology, participation in its development;

2. Artistic research - The Piano of the $21^{\text {st }}$ Century and its Future Perspectives which will serve as Case Study for the future implementation of a new research form in Georgia. It consists of several components:

- Scientific (musicological) research - The development of the expressive abilities of the piano in the context of development of academic music in the $20^{\text {th }}$ and $21^{\text {st }}$ centuries;

- Research of expressive abilities of piano; experiments with instrument;

- Composition of a large-scale piano piece, based on the results of the research, its performance and video-recording.

In the present paper we aim to present the central part of the project - the artistic research.

\section{Artistic Research Piano of the $21^{\text {st }}$ Century and its Future Perspectives}

"Piano music has come to an end and something quite different is coming. I sense it clearly: with the claviers made up to this time, there is nothing new to discover anymore," Karlheinz Stockhausen (1993) declared on October 24th 1992, at the auditorium of the Pädagogische Hochschule in Weingarten (p. 138). It is difficult not to agree with the German composer who still composed for piano before and after 1992. Though, the fact is that contemporary composers more and more rarely engage themselves with piano, especially solo piano, and the process started in the $2^{\text {nd }}$ half of the $20^{\text {th }}$ century.

Nino Jvania (2011) states that

"The piano performance has always been associated with emotional expressiveness.

Owing to the specific character of its sound the piano has become a main instrument of musical Romanticism. But the radical changes taking place in the aesthetics of New Music set new challenges not only to performers but to the instrument itself, especially to its sound (p. 47)."

\footnotetext{
${ }^{3}$ At Ilia State University, though, the students of PhD Program in Music are obliged to contextualize in their dissertations/written comments works represented in the creative part of their doctoral portfolios (Ilia State University, 2018, p. 3).
} 
The piano and its sound represent a result of a reevaluation of the priorities taking place in the $18^{\text {th }}$ century art. Against the background of global subjectivization of art, as the inner life of an individual - a subject - gradually became a central theme in art and in music particularly, the spirit of the new epoch "demanded rather spontaneous reflection of emotions" (Savshinsky, 1961, p. 179). The necessity to express flexible emotions created a need for a new instrument producing more dynamic and flexible sound than a harpsichord the leading keyboard instrument of the preceding era. As a result, the piano offered a wider range of possibilities to the performer to interpret the score in a subjective manner that emphasizes the subjective nature of the instrument. "This nature was in a full accord with the subjective expression of musical Romanticism, which, consequently, assigned a central position to the piano throughout the $19^{\text {th }}$ century" (Jvania, 2011, p. 47).

However, the present epoch compels the pianists to deprive the piano sound of its immanent feature, as it is this subjective nature that is out of accord with new priorities of the new age. Here is one of the most important of those priorities - almost every important representative of New Music talk about liberation of music from the individual, with his taste, emotions and tendency to self-expression - in whole, from the subjectiveness. "Time of exaggerated emotions in music is over," declared Karlheinz Stockhausen in a conversation with Nino Jvania (N. Jvania, personal communication, January 20, 2006). John Cage, inspired by Zen Buddhism, almost in each of his writings and lectures rejected the idea of music serving as the primary means of self-expression of composers and interpreters. Christian Wolff considers a concern for objectivity, almost anonymity as a basic one of New (Experimental) Music:

"The 'music' is a resultant existing simply in the sounds we hear, given no impulse by expression of self or personality. It is indifferent in motive, originating in no psychology nor in dramatic intentions, nor in literary or pictorial purposes. For at least some of these composers, then, the final intention is to be free of artistry and taste" (Nymann, 1999, p. 30).

Of course, this is not the only factor that initiated the ongoing diminution of interest in piano. This could be caused by quite radical reevaluation of the concept of musical sound (resulting into integration of all kinds of sounds and noises in music) on one hand, and quite active employment of technologies in music production and composition, on another hand. As a result, to quote Stockhausen (1971), "timbre and timbre-oriented pieces gain in importance, whereas monochrome pieces are almost ignored" (p. 348). The inability of piano to overcome the restrictions of equal temperament makes it even less attractive for composers of the $21^{\text {st }}$ century.

It's worth mentioning that some composers of the $20^{\text {th }}$ and $21^{\text {st }}$ centuries enriched the sound production abilities of piano, modifying the mechanism of the instrument as well as performance technique. It is quite difficult to imagine what kind of innovations the acoustic piano could present to listeners, even in case of employing electronic technologies. Has piano music really come to an end? The question is quite topical nowadays, especially for lovers and researchers of piano music. One of the best ways to answer it is to conduct the artistic research.

Any unconventional form of employment of piano in music composition - be it preparation, intentional alteration of tuning, employment of different types of extended technique - could be considered as a result of the process resembling artistic research. Comments, interviews and texts by John Cage, Helmut Lachenmann, Karlheinz Stockhausen and some other contemporary composers of great importance support this statement. The last piano cycle by Stockhausen "Natural Durations", for example, could be considered as a result of the artistic research aiming to explore the nature of a piano sound. In an unpublished conversation with Nino Jvania mentioned above he described some methods of his research - for instance, measuring the 
duration of the sounds characterized by the same parameters (pitch, intensity, attack) on different types of piano. As a result, the 24 short pieces of the cycle have the initial concept of letting the tempo and rhythms of the work be determined by how long notes sustain. Factors such as pitch register, attack intensity and use of the sustain pedal also are considered. Thus, the end result of the research is the piece of music that presents a new perspective on piano - the instrument of special historical importance that is regarded by the majority of contemporary composers as almost the obsolete one. The same could be said about the prepared piano of John Cage or the quarter-tone piano of Alois Hába.

The artistic research Piano of the $21^{\text {st }}$ Century and its Future Perspectives is conducted by the composer and two pianists who intentionally co-work to create a piece of art based on the research. The artistic research consists of the historical analysis of development of the instrument in the context of development of academic music, as well as experiments that aim at finding new methods of sound production and ways of transforming/modifying piano. The research will result into a large-scale piano piece/performance composed by Eka Chabashvili (in cooperation with Nino Jvania and Tamar Zhvania) for two pianos, one transformed piano and the virtual piano orchestra (realized with the help of video-installations and live video broadcastings via social networks). Interestingly, the artistic researchers intend to engage only with acoustic pianos, avoiding any employment of technologies (except of amplification) to modify the piano sound.

The piece reflects on one hand the evolution of the instrument through the centuries (this evolution will be described in a book accompanying the piece), and on the other hand the experiments conducted by the artistic researchers. The basic layer of the work is the sound of the $21^{\text {st }}$ century piano, while the other layers consist of allusions of various historical periods and styles related to the history of piano music - starting from 1732 when an Italian composer Lodovico Giustini composed the very first pieces - 12 Sonate de cimbalo di piano e forte exclusively for a new instrument piano. The artistic researchers aim to display the panorama of the piano music from the perspective of the contemporary epoch. The important part of the piece is an interaction with listeners - it is planned to engage them in the performance.

Thus, the research will result into a piece of art/music and not (only) in a theoretical work. The whole process will serve as a Case Study for the future implementation of a new research form in Georgia.

\section{Conclusion}

The most important long-term aim of the project participants is to establish the Artistic Research Program on institutional level at Tbilisi State Conservatoire. The establishment of the program will provide young musicians with a new opportunity to reveal their artistic potential, contributing at the same time to development of composition and performance schools in Georgia. It is obvious that it will take time to implement this idea, but the first step could be enrichment of doctoral programs with the elements of artistic research. For instance, combining the artistic and scientific parts, making it obligatory to relate them with each other could bring the doctoral programs closer to the essence of artistic research. Besides, this could serve as an example for young researchers not only at Vano Sarajishvili Tbilisi State Conservatoire but other institutions of higher education in art and music in Georgia.

The establishment of Artistic Research Program in artistic educational system of Georgia generally will contribute to integration of intellectual potential of Georgia into international system of cultural values. We do believe it is necessary to share this experience with other countries worldwide that are on the way of implementing artistic research in their educational systems. 


\section{Acknowledgments}

This paper is an output of the research project Development of Artistic Research Methodology on the Example of Exploration of the Piano of the 21st Century and its Future Perspectives. The project, as well as this work is supported by Shota Rustaveli National Science Foundation of Georgia (SRNSFG) [grant number FR-18-4275].

\section{References}

Hannula, M., Suoranta, J., \& Vaden, T. (2014). Artistic research methodology: Narrative, power and the public (2nd ed.). Peter Lang.

Ilia State University. (2018). Sadoktoro portfolios konzepzia. Sadoktoro programa: samusiko khelovneba [The concept of a doctoral portfolio. Doctoral program: Musical arts]. Unpublished manuscript.

Impett, J. (2017). Introduction. In J. Impett (Ed.), Artistic research in music: Discipline and resistance (pp. 9-12). Leuven University Press.

Jvania, N. (2011). On some generalized principles of new piano performance. Georgian Scientific Electronic Journals: Musicology and Cultural Science, 1 (7), 47-51. Retrieved from open access http://gesj.internet-academy.org.ge/ge/list_artic_ge.php?b_sec=muz\&i ssue $=2011-12$

Nyman, M. (1999). Experimental music: Cage and beyond (2nd ed.). Cambridge University Press.

Savshinsky, S. (1961). Pianist i ego rabota [The pianist and his work]. Sovetsky Kompozitor.

Stockhausen, K. (1971). Texte zur Musik 1963-1970, Band 3. DuMont Buchverlag.

Stockhausen, K. (1993). Clavier music 1992. Perspectives of New Music, 31 (2), 136-149.

V. Sarajishvili Tbilisi State Conservatoire. (n.d.). PhD Programs. Retrieved July 10, 2020, from http://www.tsc.edu.ge/index.php?m=567\&lng=geo

V. Sarajishvili Tbilisi State Conservatoire. (n.d.). Abstracts. Retrieved July 10, 2020, from http://www.tsc.edu.ge/index.php?m=535\&lng=geo

Verbeke, J. (2013). The Intrinsic Value of Artistic Research. In M. Wilson \& S. van Ruiten (Eds.), SHARE Handbook of Artistic Research Education (pp. 123-125). Valand Academy. 